\title{
Belphégor
}

\section{A Romance of Business: Genre, Scarcity, and the Businessman in the American Economic Novel}

Jason Douglas

\section{(2) OpenEdition}

\section{Journals}

\section{Electronic version}

URL: http://journals.openedition.org/belphegor/586

DOI: 10.4000/belphegor.586

ISSN: 1499-7185

Publisher

LPCM

\section{Electronic reference}

Jason Douglas, «A Romance of Business: Genre, Scarcity, and the Businessman in the American Economic Novel », Belphégor [Online], 13-1 | 2015, Online since 09 May 2015, connection on 20 April 2019. URL : http://journals.openedition.org/belphegor/586 ; DOI : 10.4000/belphegor.586

This text was automatically generated on 20 April 2019.

\section{(c) (i) $\odot$}

Belphégor est mis à disposition selon les termes de la Licence Creative Commons Attribution - Pas d'Utilisation Commerciale - Pas de Modification 4.0 International. 


\title{
A Romance of Business: Genre, Scarcity, and the Businessman in the American Economic Novel
}

\author{
Jason Douglas
}

1 As a mid-nineteenth-century romance, it is no surprise that Richard Kimball's novel, Undercurrents of Wall Street (1862), ends with the discovery of a large inheritance that rescues the first-person narrator from poverty. Charles Parkinson, a once-successful businessman, spends years struggling to provide for his family after his business collapses in the wake of a wide-spread market panic, only returning to financial security through the bequest of a substantial fortune. However, in the midst of the relief provided by his new-found wealth, Parkinson makes a rather strange confession in the novel's final sentences: "I have exposed to you many of my weaknesses. I will conclude by betraying one more. I confess I have never returned to look after my desk and two chairs in that basement office in Wall-Street" (427-28). There is, no doubt, a bit of irony in this confession. Parkinson was glad to abandon the barely profitable, dead-end job he was trapped in. But what drives the irony is the possibility that he really is betraying some weakness. The humor in saying that abandoning a miserable job is a weakness downplays but also acknowledges the fact that he really did leave something important undone. Parkinson's confession simultaneously seeks to disguise and mark some kind of discomfort with his economic situation.

2 Certainly it is a shame that Parkinson lost his business and had to work long hours for meager and uncertain pay, but once his fortunes were restored, once he could return his family to a life of comfort, it is hard to see what problem remains. If the purpose of his work was to provide for his family, then once his family was provided for, the purpose of his work was fulfilled. If jobs are merely a way of getting money, then once you have money, a job is superfluous. It is hard to see what difference there can be between the profits of Parkinson's work and his inherited wealth except the amount of money they provided. His office generated very little money and the inheritance provided a 
substantial amount. It seems as if we should be able to reduce his financial problems to simply a lack of money.

Parkinson's confession of weakness is, however, merely the last indication that the novel differentiates his work as a businessman from his inherited wealth. Undercurrents is almost entirely dedicated to describing the details of Parkinson's professional life. The book is filled with the details of market fluctuations, debt renegotiations, bankruptcy proceedings, note brokering, and discount rates. The story focuses on the technical aspects of his work as a businessman. The central tension of the novel revolves around the possibility of Parkinson's profitability on Wall Street. The inheritance that allows him to abandon his office is a complete departure from the exploration of his professional life. In fact, the bequest isn't even directly part of his personal finances. The actual heir to the fortune is a destitute young girl that Parkinson had taken in shortly after the death of her mother. Because Parkinson treated her like his own daughter, when she was unexpectedly found to be an heiress, she decided to share her fortune with those she had come to think of as family. Parkinson's economic redemption had absolutely nothing to do with the details of his business life that occupy the novel right up until the concluding chapters. The economic struggle has no connection to the economic resolution. The solution to Parkinson's financial problems comes as an outside intervention that doesn't solve any of his business difficulties so much as it makes them irrelevant.

4 Reducing Parkinson's problems to a lack of money that can be solved by an inheritance would gloss over the radical shift entailed by this financial deus ex machina. The familiarity of this kind of trope in the nineteenth-century romance threatens to erase the difference between Parkinson as a businessman and Parkinson as a wealthy man. The moment that the inheritance allows Parkinson to abandon his office is the moment that the novel abandons its interest in him as a businessman. It is clear that considering Parkinson as a man of wealth is a question of whether or not he has money. But it is not obvious what is at stake in thinking about him as a man in business. Why does the novel contain such a detailed account of business life if that account has no bearing on the economic outcome? If the story is about Parkinson as a businessman, then his success or failure as a businessman matters. To imagine that simply giving him money has any bearing on his status as a businessman is to assume that a businessman is nothing more than a consumer. But the very idea of the businessman involves the creation of value. Whether it be through invention, discovery, development, design, management, enhancement, delivery, or efficiency, what makes a businessman a businessman is that he is productive in the sense that he participates in the process of making valuable goods and services available to consumers and not necessarily in the sense of creating physical goods. Parkinson's work as a businessman is supposed to be part of that process, but the inheritance only enables consumption and makes the production of value irrelevant.

5 One way to see this is as a formal problem in which the novel shifts, without an appropriate transition, from one set of concerns to another. Undercurrents simply fails to reconcile two different questions it asks about money and value. While it is certainly true that this represents a kind of literary failure, it is a productive failure in which the movement from one question to the other raises the possibility of differentiating between the two. The failure to fully reconcile Parkinson's business finances and his personal finances makes it possible to think of him as having two separate (albeit related) financial problems. The abrupt shift in focus from one to the other makes visible precisely the kind of questions I am interested in: is the problem of whether or not Parkinson has money the 
same problem as whether or not he is able to manage his business debts and operate a profitable company? I am interested in the difference between a story about money and an economic story.

The status of the businessman and his role in the creation of economic value becomes an increasingly visible question in literature during the latter half of the nineteenth century. A flood of novels were published about merchants, financiers, stock brokers, corporate presidents, and all manner of businessmen. And what always seems to be at stake is the possibility that these individuals can contribute to the creation of economic value. The businessman emerges in literature as the character who troubles the conventional notion that simply giving someone money is a sufficient or satisfactory conclusion to an economic narrative, precisely because merely having money doesn't necessarily generate value. The businessman is the figure in literature who makes it possible to see the difference between wealth and the system that generates wealth, i.e., the economy.

While this question has important literary dimensions, it is also an important question for the economy and economics. At this historical moment, the question of the production of value is being redefined in terms of the possibility of economic management. With the rise of finance capitalism through markets for stocks, bonds, securities, futures, and credit, huge swaths of the economy were put under the control of professional managers. These businessmen were defined by their expertise in employing the available resources in the most productive and profitable fashion. The proliferation of middle management and representative ownership marked the transition to a financial economy. The idea that someone can determine the most desirable and efficient uses of available resources is a direct reflection of the conceptual changes that also are remaking economics into a kind of mathematical science. The nineteenth-century shift from political economy to economics involved the increasing use of mathematical models to describe the relationship between alternative uses of scarce resources. The notion that these relationships are measurable and based on some sort of general principles is essential for modern economics. In narrative, in practice, and in theory, what it means to think about an economic problem begins to require that we think about more than quantities of money.

8 Parkinson's efforts to save his company from bankruptcy suggest what it might mean to think of him as a businessman rather than a rich or poor man. Once Parkinson learns that all of the major lending houses which owe him money have failed, he immediately sets out to meet with his own creditors in the hope that they will accept reduced settlements. He pins all of his hopes on renegotiating his debts. Perhaps counterintuitively, the novel's use of debt renegotiation marks a concern for something other than the lack of money. Because Parkinson focuses his efforts on debt renegotiation, he never attempts to get more money. There are no attempts to secure new credit, borrow privately from friends, or liquidate assets. Parkinson opens his books to his creditors and tries to come to an agreement about how much of a repayment they can reasonably expect given his assets and liabilities. For Parkinson, it is entirely a question of how to allocate the resources he already has. Most of his creditors acknowledged the insufficiency of his funds and instead focused on determining what share of his resources could realistically expect. Although debt renegotiation necessarily involves inadequate funds, it does not operate on the assumption that the primary concern is the lack of funds. The problem that debt renegotiation solves is not how to remedy a lack of funds, but how to most acceptably 
remedy the situation with the available funds. Once you enter renegotiation, you have already accepted and moved past the insufficiency of funds.

The novel's first response to a debt problem is to search for a solution within the constraints imposed by the available resources. The work of the businessman is not to solve all problems by generating more revenue. The novel considers the possibility that financial problems can be thought of as a matter of resource allocation or management, and not quantity per se. What the businessman does might involve getting more money, but it might also involve devising ways to satisfy obligations and needs under the constraints imposed by limited resources. Although many if not most economic problems can be solved by the application of more resources, that does not mean that they must be thought of as only a problem of inadequate resources. If, for example, Parkinson rented the most desirable office on Wall Street and furnished it lavishly, then he is spending too much money on an office. If, on the other hand, every cent he earns from working 80 hours a week buys one loaf of bread, he has a problem of insufficient funds. Financial problems can be a lack of resources or they can be a matter of how resources are utilized. Up until Parkinson's financial redemption, Undercurrents focuses on how those resources can be utilized rather than on their quantitative insufficiency.

For Undercurrents, the difference between success in business and inherited wealth remains difficult to pin down. Although the novel indicates that there is a difference, the financial outcome of the novel so fully supersedes the economic problems of the businessman that the distinction is never rigorously defined. As it turns out, however, this attention to the details of business life, coupled with a retreat into the conventions of the nineteenth-century romance, is actually an important part of the growing number of novels concerned with businessmen. In the earliest American novels that, like Undercurrents, focus on business, it is not entirely clear what difference this makes. With the rise of the futures market, the limited liability corporation, and finance capitalism in general, businessmen became a normal part of the economic landscape. But it quickly becomes apparent that novels don't incorporate these figures simply because they are there. Bankers and financiers aren't part of novels just because there are now people employed as bankers and financiers. Businessmen appear in novels because they represent a particular kind of tension that drives the economic narratives in these novels. Owing to the rise of finance capitalism and of economics as a kind of science, the nature of economic problems also change the tension that drives economic narratives and, consequently, the types of characters and problems in these narratives. Although Undercurrents displays some of the concerns that will become a common part of economic narratives, later novels begin to define the nature of the changing economic problem in much more visible ways.

11 In certain respects, for example, Charles Bellamy's 1879 novel, The Breton Mills, presents some of the same concerns as Undercurrents. As the son of a mill owner, Philip Breton sees the impoverished conditions of the workers at his father's mill. They work long hours in poor conditions for little pay and they go home to a dearth of food and comfort. Like Parkinson, Breton is concerned with the living conditions of the working poor. Although he enjoys a life of ease and luxury, he is bothered by the plight of the workers and he wants to lift them out of poverty. But as only the son of a mill owner, he has neither the means nor the authority to help. Upon his father's unexpected death, however, Breton finds himself in control of the family business and fortune. Consequently, the inheritance of a large fortune promises to alleviate his financial difficulties. Breton now seems willing 
and able to help the workers. During his first days as owner of the mill, he overhears workers describing how everything will be different under his control: "they say we're not to work but four days a week now . . . wages will be more instead of less" (190). Breton, it seems, is set to usher in a new age of prosperity. And indeed, the novel closes with Breton retiring to Europe with his new bride. In both Undercurrents and The Breton Mills, financial concerns are resolved by the introduction of a large amount of money, a common trope exemplified by Horatio Alger's many novels where hard work is dramatically rewarded by an unexpected benefactor.

Despite the parity in producing financial security for Parkinson and Breton, an inherited fortune neither resolves nor makes irrelevant Breton's work as a businessman. Although Parkinson can retire with only a twinge of guilt for his weakness as a businessman, Breton doesn't have that luxury. Parkinson's financial goal - to provide for his family was fully achieved with the money he received. Breton's retirement, on the other hand, explicitly marks his complete and utter failure to achieve his financial goal. As the legal heir of a rich father, his fortune was already secured, and he was never interested in having more money for himself. Instead, his financial goal revolved around the economic condition of the workers. Selling the mills does allow him to retire in luxury, but it doesn't make the workers better off. In fact, after most of the novel is spent describing Breton's efforts to improve the lives of the workers, he is forced to suddenly and secretly sell the company before fleeing the country ahead of increasingly dissatisfied and angry mobs of workers. Even after adopting the best business reforms he can devise, Breton is never able to significantly alleviate worker poverty. Rather than a happy ending that subsumes the larger economic goal, his personal financial success produces an emphatic statement about his inability to control anything except his personal finances. The moment that he retires a wealthy man and stops being a businessman marks the moment when the narrative conspicuously gives up on the larger economic goal. The novel does nothing to disguise the fact that producing a happy ending for Breton has no effect on the well-being of the workers. It's not that Breton retires at their expense. He doesn't liquidate, bankrupt, or steal from the company. He simply sells it to a new owner. The resolution of one kind of financial problem (Breton's personal fortune) marks the persistence of another (worker poverty) and suggests what might be at stake in differentiating between personal and business finances. In this sense, these novels employ the same trope seen in novels like Alger's Ragged Dick (1868) but with a very different meaning.

13 In the first place, Breton's financial goal is different in kind than Parkinson's. Breton has enough money that he doesn't need to worry about taking care of his family. His struggle is to improve the lot of the workers. He is trying to find a way to support more than a thousand people. More important than the number is the fact that he is not concerned with them as individuals. It's not as if he knows the names, faces, circumstances, and stories of each worker and their family. Breton is concerned with the workers as a whole group, category, or class of people. He is concerned with a segment of the population. The finances of an individual can be described in terms of how much money they have. But for the finances of a population, the problem cannot be defined in terms of a single fortune or body of accumulated wealth. The financial problems of populations are defined by the larger system which generates wealth. To talk about the financial condition of the workers is to talk about the economy. The financial condition of an individual is both qualitatively and quantitatively different from the financial condition of a population. If, 
for example, Breton was skilled in spinning yarn by hand, he might sell it for profit. But it is an entirely different matter to try and spin as much yarn as can be produced by industrial spinning machines. The knowledge and skills necessary for running an industrialized mill are significantly different than the knowledge and skills necessary for operating a hand-held spindle or spinning wheel. Knowing how to spin yarn is one thing. Knowing how to build, purchase, maintain, and operate industrial machinery is another. Although cottage industry businesses might make the same products as a textile mill, they aren't the same kind of business. Each of these enterprises requires a very different set of technical skills that may result in, but is not defined by, the quantitative differences of production. The same is true for the kind of work necessary to provide for a population. Whether any particular worker at the Breton Mills has money is not the same as the system that generates the wealth to pay all of the workers.

What, then, does it mean to think about the system that generates wealth? This is precisely the kind of question that Breton runs into over and over again in his business endeavors. Almost every time the possibility is raised that Breton can help the workers, the difference between his wealth and his ability to pay higher wages comes up. In response to the aforementioned claim that Breton will bring more pay for less work, one worker expresses a kind of skeptical agreement: “Well, I don't see how the young boss is goin' to make the mill pay that fashion, but I suppose that's his lookout" (190-91). The first response of this worker is not to rejoice in the possibility of new found leisure and prosperity. His first thought is to wonder how someone can make a business operate with both higher wages and less work. If the mill doesn't pay, if it doesn't bring in a profit, where does the money to pay wages come from?

This exact same question comes up again when Breton later asks his paymaster if he can pay higher wages; "Can you, why yes, I suppose you can step right into the mills and give a hundred dollar bill to every hand, but you couldn't afford to do that way long." (203). There is no doubt that Breton has a large enough fortune to give the workers more money, perhaps even a lot more. But the issue that both the skeptical worker and the paymaster raise is not about the size of Breton's fortune. The issue is about the sustainability of paying wages as part of the cost structure of the business. The money that pays the workers and contributes to Breton's fortune comes from the mill's revenue. Breton's ability to pay the workers is ultimately owing to the money generated by the mill on an ongoing basis and not to an accumulation of capital. Just because he has the money to pay them higher wages today does not mean that he will have the means to do so in the future. The worker who wonders if Breton can "pay that fashion" is more insightful than he realizes when he says that it is "his lookout." Breton is concerned with the mechanisms by which the business generates revenue. In order to lift the workers out of poverty and not simply give them a limited number of larger paydays, he has to think about the impact that labor costs have on operating capital. No matter how much money the workers need to live in reasonable comfort, Breton can't pay them that much unless the mills can generate enough revenue. As a businessman, it is Breton's job to understand precisely these kinds of issues. In order to solve the long-term financial problems of the workers, he has to be able to answer questions about what role factors like the cost of labor play in operating a sustainable business.

The paymaster's response to Breton's inquiry about higher wages includes a subtle shift in language that suggests there are two very different ways to think about what kind of problem they are discussing. When the paymaster talks about a hundred dollars for each 
worker, he uses the word "give" rather than the word "pay." By giving the workers money, Breton would be treating his fortune like a quantity of wealth. If money is a quantity for consumption, then the question of whether or not you can afford something is a matter of simple arithmetic. All that matters when you "give" money away is how much you have. But what Breton actually asked, and what the paymaster is trying to emphasize, is that the ability to give money away isn't the same thing as the ability to pay wages. The ability to pay wages is based on the cost of production and the market price of the product. If you want to pay wages - that is, to perpetually use revenue to pay the cost of production - then wages must be determined in relation to revenue. In other words, if people aren't paid in relation to what their labor generates, somebody is giving money away. Wages derived from revenue are a renewable resource. Gifts taken from a given quantity of funds are a non-renewable resource. For Breton to help his whole population of workers, he has to pay them from a self-sustaining system and not give them money from a private fortune.

Breton's concern for the cost structure of his business reflects a shift in thinking about what it is he does as a business owner. Although awareness of the relationship between income and expense is hardly a new part of profit calculations, the work of understanding that relationship takes on a new dimension in the nineteenth-century economy. Breton may be the owner of the mill, but his ownership is not a title that guarantees profit. The novel describes the responsibilities that play a vital role in his business operations. Breton is the one who has to find the best price for raw materials. He is the one who negotiates sales contracts. He is the one who has to evaluate the feasibility of capital improvements. Breton's ownership does not make him a man of leisure. True, he does not work with his hands on the factory floor, but his duties and activities are presented as a necessary kind of work. It is his job to compare all of the different possible scenarios and aspects of buying, producing, and selling so that the business remains profitable. He has to take into consideration competition, future prices, equipment depreciation, worker productivity, and any number of other factors that determine how much money the business can bring in, and consequently, make it possible to pay the workers.

The idea that it requires some kind of specialized work or technical expertise beyond tradecraft to figure out how to pay your workers is part of a nineteenth-century, structural and conceptual change about what it means to be in business. Presenting Breton's ownership of the mill as a kind of work is not merely semantic sleight of hand where his title is changed to justify the money he receives. Calling Breton a businessman isn't a discreet way of saying he is wealthy. It describes the work he is doing. This kind of work was a necessary part of the explosive growth in industries like transportation, manufacturing, and finance. The dramatic expansion of these industries required a new kind of expertise to deal with increasingly complex questions about national markets, economies of scale, infrastructure development, collective ownership, representative management, and abstract value. While none of these issues were new in and of themselves, the degree to which they began to infiltrate every corner of the economy made their influence widely felt and highly visible. Breton's work as a businessman reflects the proliferation of business technologies that require a new way of thinking about what it means to be in business.

19 Most accounts of the history of business present these kinds of changes as fundamentally a matter of process or organization. The businessman rearranges existing economic elements to increase efficiency of production and delivery. Alfred Chandler's description 
of the modern business world in The Visible Hand (1977) is a prime example of this kind of account. Chandler documents the way that technical expertise in the administrative aspects of exchange becomes the dominant form of economic organization. He describes a "managerial revolution" that reorganizes modern business into a system made up of "many distinct operating units" that are "managed by a hierarchy of salaried executives" whose jobs "become increasingly technical and professional" (3). The modern economy revolves around managers who "coordinate" and "allocate" rather than produce. For Chandler, ceding control of production and distribution to professional management is the defining feature of the modern business world.

There is no doubt that the proliferation of business management has had a profound effect on economic and social organization. The sheer number of managers in the world and the portion of the economy under their control attests to that. Unfortunately, classifying these changes as fundamentally logistical doesn't identify the conceptual problem that they are responding to. What problem is professional management supposed to solve? Why do we even need a Philip Breton in the first place? It would be tautological to suggest that managers are a response to problems caused by economic developments like the increased scale of industrial production, widening distribution due to advances in transportation, or the complexity of financial markets. The need for structure and coordination is an inherent part of these developments and not a solution to a problem that they create. What is a factory or a railroad network if not a system of coordinated units operating under some kind of centralized control? Organizations like stock markets, limited liability corporations, and industrial plants are themselves a response to an economic problem: how do we coordinate the productive efforts of a population to deliver as much self-sustaining and self-perpetuating value as possible?

Because professional management has been "the dominant business institution in many sectors of the American economy" (Chandler 3) since at least the First World War, it can be hard to see the degree to which this kind of question represents a serious change to the nature of what an economic problem is. What it means to have an economic problem at the end of the nineteenth century is not the same as it is at the beginning. Companies with multiple layers of professional managers specializing in coordination and allocation "did not exist in the United States in 1840." The managerial revolution reflects a change to what business is and not just how we do business. This shift in the nature of economic solutions indicates a shift in the nature of an economic problem, which is precisely the tension that novels like Undercurrents and The Breton Mills are sensitive to. The attempt to make characters successful in business, coupled with the retreat into inherited wealth, reflects the struggle within these novels to identify what is at stake in thinking about the difference between a money problem and an economic problem.

As I have presented it, Parkinson and Breton abandon the economic principles of modern business when they retire, but in another sense, they are merely returning to an earlier definition of the economic. These novels reflect the transformation of economics from a physical science to a mathematical and social science. Modern economics has its origins in eighteenth-century political economy, which began as a study of wealth. The title of Adam Smith's most famous work, An Inquiry into the Nature and the Causes of the Wealth of Nations (1776), is as definitive as it is obvious. Wealth is the subject matter of political economy. But wealth must here be understood as particularly material. Wealth is the class of objects whose physical properties satisfy human wants. Like many of Smith's contemporaries, James Steuart defines political economy as dealing specifically with the 
goods necessary for supporting the life of man. "The principle object of this science is to secure a certain fund of subsistence" (2). Modern economics arises from a discipline that is preoccupied with studying the production of goods for consumption. It is easy to see, given the focus on this material aspect of wealth, how a large sum of money, like an inheritance, can be a solution to an economic problem that revolves around consumption. However, during the course of the nineteenth century, perhaps because of the aforementioned developments in production and distribution, the limitations of a material explanation of wealth begin to emerge. The ability of an object to satisfy human wants depends on its material properties as well as the availability of that object. It doesn't matter if something will fulfill your needs or desires if you can't get that thing. Although other concepts like individual self-interest and the social nature of exchange are essential to what economics becomes, the idea of scarcity plays an increasingly important role in the evolution of the study of wealth. Early accounts of scarcity include an object's relative abundance as just another material quality. James Maitland's 1804 writings about the nature of wealth demonstrate the way that scarcity is, at first, simply added to existent notions: "the value, therefore, of all commodities depends upon the possession of a quality that makes them the object of man's desire, and the circumstance of their existing in a certain degree of scarcity" (15).

Although it is completely logical that the availability of a thing influences its ability to satisfy human wants, the force of this change isn't immediately apparent. It isn't until later in the century that the potential for the idea of scarcity to fundamentally alter the nature of what it means to study wealth becomes evident. W. Stanley Jevons's work in the 1860s concerning the English coal industry is one of the earliest examples of how scarcity will become a central part of economics. Jevons examines the amount of coal accessible in English mines in relation to ever increasing industrial and domestic use. The Coal Question begins with a bit of anxiety about the possibility of exhausting the supply. "It can be no matter of surprise that year by year we make larger draughts upon a material ... but it is at the same time impossible that men of foresight should not turn to compare with some anxiety the masses yearly drawn with the quantities known or supposed to lie within these islands" (viii). But by the time he concludes, Jevons is no longer asking a strictly quantitative question. "Are we wise in allowing the commerce of this country to rise beyond the point at which we can long maintain it?" (344). The concern for any numerical quantity of coal has been subsumed by its status as a finite resource within an ongoing system of commerce. The central question is about the system that produces wealth rather than the objects of wealth. In the final sentences of the study, we can see how thinking about scarce resources within a system of production entails a very different way of defining an economic problem. "If we lavishly and boldly push forward in the creation and distribution of our riches, it is hard to over-estimate the pitch of beneficial influence to which we may attain in the present. But the maintenance of such a position is physically impossible. We have to make the momentous choice between brief greatness and longer continued mediocrity" (349, emphasis added). The first sentence is compatible with traditional notions of economics as a science of wealth. But the last two sentences assert the primacy of two elements that will come to define the nature of economic inquiry: "physical impossibility" and "choice." Economic scarcity is about the inescapable constraints imposed by limited resources and the possibility of making informed decisions based on recognizing these constraints. Economics becomes the science of determining the various consequences of alternative uses of resources based on the given 
conditions. This is exactly the same problem as Breton trying to figure out how much he can pay his workers.

Just as professional management becomes the dominant business institution, economics becomes a science of scarcity. In 1932, Lionel Robbins' famous definition of economics as "the science which studies human behavior as a relationship between ends and scarce means which have alternative uses" (16) signaled the conceptual dominance of economic scarcity. Economics could no longer be a question of any particular characteristic of wealth. Economics had become the science that explains the various possible forms of the system that produces, exchanges, and consumes wealth. For the economist, economic scarcity is a matter of accurately describing the economy. For businessmen, it is a question of the most efficient and productive institutional organization. For the business novel, however, it produces a kind of formal problem that is best summarized by the subtitle of Undercurrents: a romance of business. Self-designation as a romance is quite common in nineteenth-century novels, even among those that focus on businessmen. The romance aspect of these novels lies in their commitment to producing the morally appropriate outcome for deserving individuals. Hard-working men and women of good character should be rewarded, or (what amounts to the same thing) it is a tragedy if they are not. Novels, as romances, demonstrate what is supposed to happen to people. But when these novels include businessmen, their status as businessmen requires that they achieve a particular kind of success. As we see for Breton and Parkinson, having money isn't enough to make you successful in business.

Money in and of itself can't answer the problems of businessmen because they are part of the economic institutions that produce the wealth that supports populations and nations. Even considering only the fact that an economy has to produce over time - not thinking about questions of population growth, immigration, or technological advancement - it is clear that satisfying human needs and wants is an ongoing process. There is always more demand; demand that no fortune or accumulated wealth can fully satisfy. Although a science of economic scarcity promises to determine the best way to coordinate production and allocate resources, it also promises to reveal the limitations of what is possible. When you ask how much you can do, you are automatically asking what you can't do as well. That is Jevons's whole point about needing to choose between "brief greatness and longer continued mediocrity." Although the prospect of having some is better than the prospect of having none, accepting a reduced standard of living as a good solution isn't quite the same kind of triumph or tragedy that a romance imagines as an appropriate outcome, but this is the tension required of a novel that takes seriously the idea of a character as a businessman.

The formal problem of the business novel resides in a dual set of commitments to account for both the morally appropriate outcome and the limitations imposed on the businessman by scarcity. Although not inherently contradictory, these commitments don't necessarily involve the same kind of problem. The trajectory of a novel as a romance doesn't necessarily align with the tension entailed by considering a problem of scarcity. In one sense, this means that the business novel raises a question that it can't fully resolve. How do you reconcile the fact that the best solution a businessman might offer can be both the best possible solution and still not be good enough? How do you make sure that deserving individuals are rewarded when the mechanisms for producing the appropriate outcome are just as likely to tell you why they can't be rewarded? To some degree, business novels are always retreating from the limitations that arise from 
scarcity. But in a way, this is precisely the point. By raising and then retreating from questions of scarcity, these novels make the problem visible. It is only in conspicuously abandoning a scarcity problem that the nature of that problem can be seen. If there is any meaning or force in identifying novels as business novels, it is not found in a discussion of the nature of money, commodities, labor, etc. The force of a business novel arises from the commitment to producing the tension generated by an attempt to reconcile the demands of the novel and the changing nature of an economic problem, a tension that cannot be reduced to either the wealth or poverty of any individual.

The usefulness of novels like Undercurrents or The Breton Mills in producing a visible account of scarcity is completely dependent on both their failure to follow through with an account of business and on their retreat into the conventions of the romance novel. The retreat is necessary because it makes the economic problem visible in a way that it would not be if it was fully resolved. Only when the businessman stops being a businessman can we see the difference between the poverty of the workers and the problem of managing the system that might be able to alleviate poverty. In a way, despite offering the possibility of increased efficiency and growth through business expertise, a science of scarcity will always be a kind of tragedy because it simultaneously determines what it can't possibly deliver. And it is the romantic commitment, the retreat from the businessman, that makes it possible to see that problem. The difficulty of achieving morally appropriate outcomes within the horizon of economic scarcity is both the account that the business novel produces and the formal challenge it faces as a romance of business.

\section{BIBLIOGRAPHY}

Charles Bellamy, The breton mills, New York, G.P. Putnam, 1879.

Alfred Chandler, The visible hand, Cambridge, MA, Harvard UP, 1977.

W. Stanley Jevons. The coal question, London, Macmillan, 1865.

Richard Kimball, Undercurrents of wall street, New York, G.P. Putnam, 1862.

James Maitland, Inquiry into the nature and origin of public wealth, Edinburgh, Neill and Co., 1804.

Lionel Robbins, An essay on the nature and significance of economic science, London, Macmillan, 1932.

Adam Smith, An inquiry into the nature and causes of the wealth of nations, London, W. Strahan and T. Cadell, 1776.

James Steuart, An inquiry into the principles of political economy, Dublin, A. Millar and T. Cadell, 1770. 


\section{ABSTRACTS}

The subtitle of Richard Kimball's novel, Undercurrents of Wall Street, represents the central tension of the American business novel that emerges during the second half of the nineteenth century. The novel calls itself as a "romance of business." As a romance, there is never any doubt that the story must restore the fortunes lost by the main character when his business fails. As a business narrative, a large part of the text explores the myriad ways in which market conditions prevent his return to profitability. The tension between the desire to make him a wealthy man and the difficulty of making him a successful businessman is the kind of tension that becomes the defining feature of the business novel. These novels, as economic narratives, have a logical commitment to market and resource constraints. But as novels, such texts are also committed to reinforcing the relationship between moral behavior and personal success. These novels reflect a dramatic shift in the conceptual landscape that transformed economics from a science of wealth to a science of scarcity. This conceptual shift is reflected in the structural reorganization of the business world to favor a new class of professional managers. The businessman becomes an important financial technology as well as the central element of economic narratives. The economic novel must be understood as an attempt to reconcile the mathematics and calculation of economics as a rising science of scarcity with the genre constraints of the American romance.

\section{INDEX}

Keywords: businessman, scarcity, romance, novel, economics

\section{AUTHOR}

\section{JASON DOUGLAS}

University of Illinois at Chicago, Doctoral Candidate 